\title{
Introduction: \\ The Politics of French and German Cinema, 1930-1945
}

\author{
Brett Bowles, Guest Editor
}

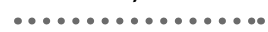

$\mathrm{T}$ he politics of French and German cinema between the onset of the Great Depression and the end of World War II is far from a new topic of study. However, scholars have typically focused on one country or the other, rather than comparing the two, and prioritized high-profile directors (for example, Jean Renoir, Jean-Paul Le Chanois, Leni Riefenstahl, and Veit Harlan) whose work benefited from direct party sponsorship and served a clearly propagandistic function. Reflecting the evolution of cultural history and film studies over the past decade, this collection of essays seeks to enrich the traditional approach in three ways. The first is by expanding the definition of politics beyond official party or state discourse to include power-related issues such as representation of gender and gender roles; access to material resources including funding and technology; relationships between film creators and industry or government officials; and competition between commercial and ideological priorities in film production, censorship, and distribution.

A second innovation involves broadening the corpus of films deemed worthy of study by setting aside canonical classics (such as Riefenstahl's Triumph of the Will and Renoir's Life is Ours) in favor of less-studied works with more subtle political content. As Nazi Propaganda Minister Joseph Goebbels remarked in his 26 April 1928 diary entry critiquing Sergei Eisenstein's October, the best political propaganda is the most subtle, woven into the affective fabric of entertainment and rendered compelling through cinematic style and technique. By emphasizing the failures and limitations of cinema in shaping public opinion both within the Reich and abroad, the essays included here on Nazi cinema show that Goebbels' own film propaganda was often restricted in its appeal and could even produce backlash among spectators. The third innovation consists of assessing the political uses and impact of film in France and Germany comparatively, through thematic pairs of essays featuring a case study from each country. 
As the first four articles in this issue reveal, there were fundamental continuities between the two nations with regard to film politics. Cheryl Koos and Jo Fox demonstrate the crucial importance of motherhood as a civic duty both for the Nazis and across the entire political spectrum of ThirdRepublic France. Similarly, Franz Birgel and Steve Ungar highlight the difficulties of producing and distributing Marxist-inspired "social cinema" prior to the Nazis' seizure of power and the formation of the French Popular Front.

The last four articles address film politics during and immediately after World War II. While Roel Vande Winkel examines the conflicting ideological and commercial priorities that the Nazis faced in exporting filmed propaganda to France and neighboring occupied countries, my own contribution investigates how similar factors shaped the choices made by high-profile French director Marcel Pagnol. Finally, David Culbert and Sylvie Lindeperg assess films by the Nazis and the French Resistance meant to rally public support by presenting emotionally compelling, revisionist versions of the past.

Taken collectively, these essays demonstrate the value of cinema as an object of study for the history not only of politics, but of society, economics, and culture as well. Because the study of cinema demands attention from each of these fields, it offers a basis for revising and enriching previous scholarship generated within traditional, monodisciplinary frameworks. 